\title{
UPAYA MENINGKATKAN HASIL BELAJAR MATEMATIKA MELALUI MODEL PEMBELAJARAN TGT PADA MATERI TURUNAN FUNGSI ALJABAR
}

\author{
Yeni Yulianti ${ }^{1}$, Mohamad Syafi'i ${ }^{2}$, Abdul Hakim Ma'ruf ${ }^{3}$ \\ ${ }_{1,2,3}$ Pendidikan Matematika, STKIP Kusuma Negara \\ abdulhakimmaruf@gmail.com
}

\begin{abstract}
Abstrak
Tujuan Penelitian ini adalah untuk memperbaiki kualitas pembelajaran dan meningkatkan keaktifan siswa serta hasil belajar matematika siswa melalui model pembelajaran kooperatif tipe team games tournament (TGT) pada materi Turunan Fungsi Aljabar di kelas XI MIPA 3 SMAN 1 Leuwiliang semester genap tahun pelajaran 2017/2018. Metode penelitian ini penelitian tindakan kelas yang mengikuti model Kurt Lewin. Penelitian ini mencakup 3 siklus dimana masing-masing siklus mencakup 4 tahap yaitu planning (perencanaan), acting (pelaksanaan), observing (observasi), reflecting (refleksi). Waktu penelitian adalah 3 bulan yaitu dari bulan Februari 2018 sampai bulan Mei 2018 dengan subjek penelitian sebanyak 36 siswa, sedangkan data dikumpulkan melalui tes, wawancara, dan observasi. Hasil penelitian menunjukan bahwa terjadi perbaikan/peningkatan kualitas pelaksanaan pembelajaran yaitu pada siklus I sebesar79,38\%, siklus II sebesar $88,13 \%$ dan siklus III sebesar $91,88 \%$ dan perbaikan/peningkatan keaktifan siswa yaitu padasiklus I sebesar $69 \%$, siklus II sebesar $76 \%$, dan siklus III sebesar91\%, serta terjadi peningkatan hasil belajar matematika yang signifikan yang dibuktikan dengan tingkat ketuntasan hasil belajar siswa pada setiap siklus meningkat yaitu pada siklus Isebesar 58,33\%, siklus Iisebesar $66,67 \%$, siklus IIIsebesar 80,56\%,dan hasilwawancarayang dilakukan menyimpulkan bahwa belajar matematika dengan menggunakan model pembelajaran kooperatif tipe team games tournament (TGT)adalah menyenangkan bagi siswa.Kesimpulan yang dapat diambil peneliti dari penelitian tindakan kelas ini adalah bahwa belajar matematika dengan menggunakanmodel pembelajaran kooperatif tipeteam games tournament (TGT)dapat meningkatkan kualitas pembelajaran dan keaktifan siswa serta hasil belajar matematika siswa.
\end{abstract}

Kata Kunci: Model TGT, Turunan Fungsi, Hasil Belajar.

\section{Abstract}

he purpose of this study was to improve the quality of learning and improve student activity and student mathematics learning outcomes through cooperative learning model team games tournament (TGT) on Algebra Function Derivative material in class XI MIPA 3 SMAN/1 Leuwiliang even semester 2017/2018 school year. this study is a class action research that follows the model of Kurt Lewin. This study includes 3 cycles where each cycle includes 4 stages, namely planning (planning), acting (implementation), observing (observation), reflecting (reflection). The research period is 3 months, from February 2018 to May 2018 with 36 research subjects, while data is collected through tests, interviews, and observations. The results showed that there was an improvement / improvement in the quality of learning implementation, namely in the first cycle of $79.38 \%$, the second cycle was $88.13 \%$ and the third cycle was $91.88 \%$ and the improvement / improvement of student activity was in cycle I of $69 \%$, cycle II at $76 \%$, and the third cycle at $91 \%$, and there was a significant increase in mathematics learning outcomes as evidenced by the level of completeness of student learning outcomes in each cycle increased, namely in the cycle of $58.33 \%$, the cycle was $66.67 \%$, cycle III was $80,56 \%$, and the results of interviews conducted concluded that learning mathematics using the cooperative learning model type team games tournament (TGT) was fun for students. The conclusion that researchers could take from this classroom action research was that learning mathematics using cooperative learning models typeteam games tournament (TGT ) can improve the quality of student learning and activity as well as the results of the bell teaching mathematics students.

Keywords: TGT Model, Derivative Function, Learning Outcomes. 


\section{PENDAHULUAN}

Tujuan pendidikan nasional menurut Undang-undang Nomor 20 Tahun 2003 Tentang Sistem Pendidikan Nasional, Pasal 3, adalah mengembangkan potensi peserta didik agar menjadi manusia yang beriman dan bertakwa kepada Tuhan Yang Maha Esa, berakhlak mulia, sehat, berilmu, cakap, kreatif, mandiri, dan menjadi warga negara yang demokratis serta bertanggung jawab. Hingga saat ini pemerintah Indonesia terus-menerus berupaya untuk meningkatkan kualitas pendidikan di Indonesia agar tercapainya tujuan pendidikan nasional mulai dari perbaikan sarana dan prasarana pendidikan, pendataan untuk program kesejahteraan guru, serta berbagai pelatihan kualitas guru melalui uji kompetensi guru yang sudah dimulai sejak tahun 2015 dan masih dikembangkan lagi sampai dengan sekarang.

Kemajuan bangsa Indonesia salah satunya ditentukan oleh kemajuan pendidikan bangsa Indonesia yang tolak ukurnya adalah tercapai atau tidaknya tujuan pendidikan nasional Indonesia. Dalam hal ini, pemerintah pun senantiasa memantau perkembangan zaman sehingga terus berupaya melakukan inovasi-inovasi pada kurikulum yang diterapkan di Indonesia. Hingga saat ini, sejak Indonesia merdeka tahun 1945, Indonesia sudah mengalami inovasiinovasi kurikulum dari kurikulum tahun 1947 sampai kurikulum 2013 yang sedang kita jalankan saat ini. Inovasiinovasi pada kurikulum tersebut tujuannya tidak lain adalah demi tercapainya tujuan pendidikan nasional Indonesia dan untuk menyesuaikan dengan perkembangan dunia agar bangsa Indonesia dapat bersaing secara global.

Matematika disebut-sebut sebagai ratunya ilmu pengetahuan. Perkembangan dan kemajuan komputerisasi pada saat ini tidak lain karena peran ilmu matematika. Sebagai ratunya ilmu pengetahuan, matematika memiliki peran yang sangat penting dalam perkembangan ilmu pengetahuan dan teknologi karena dunia saat ini sudah serba komputerisasi dan semakin canggih dari waktu ke waktu.Sehubungan dengan betapa pentingnya posisi matematika dalam perkembangan ilmu pengetahuan dan teknologi namun pada kenyataannya matematika masih kurang diminati oleh siswa pada pembelajaran di sekolah, banyak siswa menganggap matematika itu pelajaran yang sulit dan membosankan sehingga mereka kurang menyukai pelajaran matematika.

Pada waktu perkenalan dengan siswa baru di tahun ajaran baru pada 2017, penulis mewawancarai tiga kelas, yaitu kelas X di suatu sekolah yang siswanya masingmasing berjumlah lebih kurang 28 siswa. Ternyata hanya sebagian kecil saja yang menyukai matematika, sebagian besar dari mereka tidak menyukai matematika karena mereka menganggap matematika itu sulit, menegangkan, dan membosankan sehingga minat terhadap pelajaran matematika di beberapa kelas tersebut sangat rendah dan hasil belajar matematika pun akhirnya menjadi rendah.

Kurang diminatinya pelajaran matematika di sekolah menjadi permasalahan penting yang dihadapi oleh guru pada proses pembelajaran. Kurangnya kesiapan dan perencanaan pembelajaran menjadikan pembelajaran kurang efektif dan membosankan. Model dan metode pembelajaran pun seharusnya disesuaikan dengan kondisi kelas agar pembelajaran menjadi bermakna dan menarik perhatian siswa. Namun kebanyakan guru matematika memilih metode ceramah, kemudian latihan soal, dan seterusnya sehingga suasana belajar menjadi monoton. Permasalahan-permasalahan pada proses pembelajaran tersebut tentunya berpengaruh pada hasil belajar matematika siswa.

Fakta pada kegiatan observasi di kelas XI SMAN 1 Leuwiliang pada tahun pelajaran 2017/2018 semester ganjil, hasil belajar matematika siswa pada materi induksi matematika dengan KKM 76 dengan metode ceramah di kelas XI MIPA 1 yang mencapai KKM hanya sebanyak $12,8 \%$, di kelas XI MIPA 2 yang mencapai KKM hanya sebanyak 27,5\%, di kelas XI MIPA 3 yang mencapai KKM hanya sebanyak 5,6\%, di kelas XI MIPA 4 yang mencapai KKM hanya sebanyak 10,8\%, di kelas XI MIPA 5 yang mencapai KKM hanya sebanyak 10\%, dan di kelas XI IPS 3 yang mencapai KKM hanya sebanyak 13,5\%.

Dengan menganalisa data tersebut, peneliti menduga bahwa model pembelajaran yang monoton, tidak variatif dan kurang menarik minat siswa menjadi salah satu penyebab rendahnya hasil belajar matematika siswa SMAN 1 Leuwiliang. Kegiatan pembelajaran seharusnya mengacu pada penggunaan metode dan media pembelajaran dalam rangka membahas materi sehingga tujuan pembelajaran dapat dicapai secara optimal. Belajar merupakan sebuah kegiatan yang berproses dengan sedemikian rupa dalam proses dialektis untuk kemudian bisa memperoleh sesuatu yang bermakna bagi kepentingan pebelajar (Moh. Yamin: 2015 )

Menyikapi hal tersebut, penulis merasa perlu mengadakan upaya-upaya untuk meningkatkan hasil belajar matematika siswa. Permasalahan hasil belajar ini jangan sampai dibiarkan terus-menerus terjadi karena inilah saat dimana guru harus bisa membuktikan kredibilitasnya sebagai guru yang profesional. Tugas guru bukan hanya menyampaikan materi pelajaran dan kemudian menilai. Tapi harus melakukan evaluasi, merefleksi apa yang terjadi, dan melakukan tindak lanjut agar pada pembelajaran selanjutnya bisa meningkat lebih baik lagi.

Sekiranya permasalahan ini tidak mendapat perhatian serius, maka kualitas pendidikan tidak akan bisa mengalami peningkatan. Bagaimana bisa generasi penerus 
bangsa bisa menyesuaikan diri dengan perkembangan zaman di era globalisasi ini kalau masalah mendasar dalam proses pembelajaran di sekolah saja tidak ada yang memperhatikan. Jika kita hanya berdiam saja dan malas untuk mencari solusi,tidak ada upaya untuk meningkatkan hasil belajar siswa di sekolah, maka generasi penerus bangsalah yang menjadi korbannya, padahal kunci kemajuan suatu bangsa ada pada generasi penerus bangsa. Namun, sekiranya masalah ini diperhatikan dan menimbulkan kesadaran bagi para guru di Indonesia untuk selalu terus berupaya meningkatkan kualitas pembelajaran di kelasnya masing-masing, maka penulis berharap akan ada peningkatan kualitas sumber daya manusia generasi penerus bangsa Indonesia, dan apa yang dicita-citakan untuk mencapai tujuan nasional pendidikan bisa tercapai, dan pada akhirnya generasi penerus bangsa bisa mengembangkan ilmu pengetahuan dan teknologi sehingga bisa bersaing dengan bangsa-bangsa lain di dunia.

Sesuai dengan prinsip penelitian tindakan kolaborasi melalui pendekatan penelitian tindakan kelas, penelitian tindakan dilakukan pada materi ajar (KD) yang sedang berjalan di kelas (sekolah). Jadi, sesuai program semester genap Kurikulum 2013, materi yang akan diberikan tindakan adalah materi turunan fungsi aljabar yang terdapat dalam mata pelajaran matematika. Artinya apakah tindakan yang diberikan pada KD tersebut dapat meningkatkan hasil belajar matematika siswa.

Berfokus pada faktor guru dan karakter siswa dengan latar belakang yang berbeda-beda yang menjadi faktor penyebab hasil belajar matematika yangsangat rendah, model pembelajaran kooperatif bisa menjadi salah satu cara untuk meningkatkan hasil belajar matematika siswa. Banyak sekali pembelajaran kooperatif yang dapat digunakan. Namun, pada kesempatan ini penulis lebih tertarik dengan model pembelajaran kooperatif tipe team games tournament (TGT) yang menurut penulis cocok digunakan pada pembelajaran matematika pada materi turunanfungsi aljabar yang diharapkan bisa menarik minat dan perhatian siswa sehingga pembelajaran di kelas menjadi bermakna dan tidak membosankan dan akhirnya hasil belajar matematika siswa pun meningkat.

"Team Games Tournament (TGT) merupakan salah satu strategi pembelajaran kooperatif yang dikembangkan oleh Slavin untuk membantu siswa meninjau kembali dan menguasai materi pelajaran. Slavin menemukan bahwa Team Games Tournament (TGT) berhasil meningkatkan skill-skill dasar, pencapaian, interaksi positif antarsiswa, harga diri, dan sikap penerimaan pada siswa-siswa lain yang berbeda (Miftahul Huda: 2015), pendapat lain mengemukakan Menurut Saco, dalam TGT siswa memainkan permainan dengan anggota-anggota tim lain untuk memperoleh skor bagi tim mereka masing-masing.
Permainan dapat disusun guru dalam bentuk permainan berupa pertanyaan-pertanyaan yang berkaitan dengan materi pelajaran. Kadang-kadang dapat juga diselingi dengan pertanyaan yang berkaitan dengan kelompok (identitas kelompok mereka) (Rusman: 2016 ).

\section{METODE}

Penelitian ini bertujuan untuk melakukan upaya peningkatan hasil belajar matematika siswa pada materi turunan fungsi aljabar melalui model pembelajaran kooperatiftipe team games tournament (TGT) di kelas XI MIPA 3 SMAN 1 Leuwiliang semester genap tahun pelajaran 2017/2018. Penelitian tindakan kelas ini dilaksanakan di SMAN 1 Leuwiliang yang beralamat di Jl. Raya Leuwiliang No. 47 Kabupaten Bogor Kode Pos 16640. Adapun alasan dalam pemilihan tempat ini yaitupenulis sebagai peneliti adalah guru mata pelajaran matematika(wajib) kelas XI di sekolah ini sehingga akan memberikan kemudahan dan keleluasaan kepada peneliti selama proses penelitian ini berlangsung. Penelitian ini dilaksanakan pada semester genap tahun pelajaran 2017/2018 selama 3 bulan yaitu pada bulan Februari2018 s.d bulan Mei 2018 sesuai dengan kalender pendidikan pada waktu kegiatan belajar mengajar aktif dengan menggunakan jadwal sekolah sehingga penelitian ini tidak mengganggu proses pembelajaran yang sudah ada.

Metode Penelitian yang digunakan oleh peneliti adalah metode Penelitian Tindakan Kelas (PTK) atau Classroom Action Research(CAR) dengan menggunakan pendekatan kualitatif. Pada prinsipnya penelitian tindakan kelas diterapkan untuk mengatasi suatu suatu permasalahan yang terdapat di dalam kelas. Penelitian Tindakan Kelas (PTK) merupakan bentuk penelitian kolaboratif yang dilakukan pendidik untuk memperbaiki proses pembelajaran yang telah dilakukan guna meningkatkan hasil belajar siswa melalui tahapan-tahapan yang dikenal sebagai siklus. Penelitian Tindakan Kelas (PTK) adalah penelitian yang dilakukan oleh guru di kelasnya sendiri dengan cara (1) merencanakan, (2) melaksanakan, dan (3)merefleksikan tindakan secara kolaboratif dan partisipatif dengan tujuan memperbaiki kinerjanya sebagai guru, sehingga hasil belajar siswa dapat meningkat ( Wijaya Kusumah, Dedi Dwitagama: 2012). Menurut Carr dan Kemmis, PTK adalah suatu bentuk penelitian refleksi diri yang dilakukan oleh para partisipan dalam situasi sosial untuk memperbaiki rasionalitas dan kebenaran tentang praktikpraktik sosial atau pendidikan yang dilakukan sendiri, pengertian mengenai praktik-praktik tersebut, dan situasisituasi dimana praktik-praktik tersebut dilaksanakan. Sedangkan menurut McNiff, PTK adalah bentuk penelitian reflektif yang dilakukan oleh guru sendiri yang hasilnya dapat dimanfaatkan sebagai alat untuk pengembangan 
keahlian mengajar dan merupakan penelitian tentang, untuk, dan oleh masyarakat/kelompok sasaran dengan memanfaatkan interaksi, partisipasi, dan kolaboratif antara peneliti dan kelompok sasaran (Wijaya Kusuma dan dedi dwitagama: 2012).

Penelitian ini menggunakan desain penelitian tindakan kelas berbentuk 3 siklus dan merupakan model PTK dari Kurt Lewin. Setiap siklus terdiri dari empat tahapan yaitu perencanaan tindakan (planning), pelaksanaan tindakan (acting), observasi (observing), dan refleksi (reflecting). 1) Planning (Perencanaan Tindakan) Perencanaan tindakan dimulai dari proses identifikasi masalah yang akan diteliti, termasuk hasil prapenelitian. Kemudian merencanakan tindakan yang akan dilakukan, termasuk menyusun perangkat pembelajaran yang diperlukan dan lain-lain. 2) Acting (Pelaksanaan Tindakan) Pelaksanaan tindakan adalah pelaksanaan pembelajaran di kelas dengan menggunakan perangkat pembelajaran mulai dari kegiatan awal,kegiatan inti, hingga kegiatan akhir sesuai dengan RPP. 3) Observing (Observasi) Observasi adalah pengamatan selama berlangsungnya kegiatan pembelajaran yang dilakukan oleh kolaborator dan/atau observer secara simultan (bersamaan pada saat pembelajaran berlangsung). 4) Reflecting (Refleksi) Refleksi adalah kegiatan mengevaluasi hasil analisis data bersama kolaborator yang akan direkomendasikan tentang hasil suatu tindakan yang dilakukan demi mencapai keberhasilan penelitian dari seluruh aspek/indikator yang ditentukan.

Pengambilan data sangat penting bagi peneliti, sehingga data yang hendak diperoleh dapat berasal dari sumber data yang terdiri dari: Informan, yaitu subjek yang diteliti (siswa). Subjek penelitian adalah siswa kelas XI MIPA 3 SMAN 1 Leuwiliang yang berjumlah 36 orang dengan komposisi 14 siswa laki-laki dan 22 siswa perempuan. Key informan, yaitu orang yang dikroscek untuk membuktikan kebenaran jawaban informan (guru yang berkolaborasi dengan peneliti). Analisis data hasil penelitian skripsi berbasis penelitian tindakan kelas dengan statistik deskriptif, yaitu analisis data sederhana yang melalui tahapan berikut: 1. Reduksi Data Dalam tahap ini, peneliti memilih dan memilah data yang relevan serta data yang tidak relevan (data yang tidak relevan dibuang). 2 . Deskripsi Data Dalam tahap ini, peneliti memaparkan datadata yang terseleksi dalam bentuk (urutan jenis data): a. Data hasil penilaian pelaksanaan pembelajaran di kelas. $b$. Tabulasi, menghitung rata-rata serta menggambarkan diagram histogram dan poligon frekuensi.c. Analisis dan interpretasi data. c. Membuat diagram histogram dan poligon frekuensi.

a) Data hasil observasi keaktifan siswa

(1) Tabulasi, menghitung rata-rata serta menggambarkan diagram histogram dan poligon frekuensi.

(2) Analisis dan interpretasi data.

(3) Membuat diagram histogram dan poligon frekuensi.

b) Data Hasil Belajar Siswa
Teknik perhitungan data hasil belajar siswa dilakukan dengan langkah-langkah berikut:

(1) Tabulasi nilai hasil belajar.

(2) Menghitung rata-rata dan persentase.

(3) Menyusun Tabel Distribusi Frekuensi (TDF) sesuai dengan aturan Sturgess, yaitu:

- Menentukan nilai rentang (range)

Nilai rentang diperoleh dari nilai terbesar dikurangi nilai terkecil. Rentang $(\mathrm{R})=$ nilai terbesar - nilai terkecil.

- Menentukan banyak kelas (K)

- $\mathrm{K}=1+3,3 \log \mathrm{n}$, dimana $\mathrm{n}=$ jumlah siswa(responden)

- $\quad$ Menentukan panjang kelas $(\mathrm{P})$ $\mathrm{P}=\frac{\mathrm{R}}{\mathrm{K}}$

(4) Menyusun Tabel Distribusi Frekuensi yang terdiri atas kolom nomor, interval nilai, nilai tengah,frekuensi, dan persentase.

(5) Membuat diagram histogram dan poligon frekuensi. c) Verifikasi Data Dalam tahap ini, peneliti menginterpretasi data berdasarkan deskripsi data.

Dalam memeriksa keabsahan/memvalidasi data peneliti menggunakan dua jenis triangulasi, yakni triangulasi peneliti dan triangulasi sumber. Adapun triangulasi peneliti dilakukan menggunakan tiga sumber data, yakni peneliti, kolaborator I, dan kolaborator II. Sedangkan untuk triangulasi sumber, peneliti menggunakan tiga teknik pengumpulan data, yakni observasi, tes, dan wawancara. Sedangkan Kriteria Keberhasilan Penelitian

Penelitian tindakan kelas diasumsikan berhasil bila dilakukan tindakan perbaikan kualitas pembelajaran, maka akan berdampak terhadap perilaku peserta didik dan hasil belajar. Urutan kriteria keberhasilan penelitian secara logika/ilmiah disusun kembali menjadi:

1. Kriteria keberhasilan pelaksanaan pembelajaran dan keaktifan siswa minimal 'baik' (kriteria ini untuk tujuan umum dari tujuan penelitian).

2. Kriteria keberhasilan hasil belajar matematika siswa minimal $80 \%$ dari jumlah peserta didik yang mencapai Kriteria Ketuntasan Minimum (KKM) yang ditetapkan, yaitu 76 .

\section{HASIL DAN PEMBAHASAN}

Penelitian tindakan kelas ini dilakukan di SMAN 1 Leuwiliang oleh seorang mahasiswa yang juga adalah guru di sekolah tersebut bersama dua orang guru lainnya sebagai kolaborator. Penelitian ini dimulai sejak peneliti melakukan refleksi pada hasil belajar matematika siswa yang rendah pada semester ganjil, kemudian pada semester genap peneliti mulai melakukan kegiatan observasi dan melakukan kegiatan pra tindakan. Tes awal tidak dilakukan secara khusus, karena peneliti menjadikan hasil belajar matematika siswa pada materi sebelumnya sebagai acuan mengukur kemampuan awal siswa. Subjek yang diteliti adalahsiswa kelas XI MIPA 3 yang berjumlah 36 orang dengan komposisi 14 siswa laki-laki dan 22 siswa perempuan. 
Penelitian ini dilaksanakan dalam tiga siklus yang dilakukanuntuk memperbaiki kualitas pembelajaran dankeaktifansiswa serta hasil belajar siswa pada mata pelajaran matematika melalui model pembelajaran kooperatif tipe team games tournament (TGT). Setiap siklus melalui beberapa tahapan, yaitu perencanaan, pelaksanaan,observasi, dan refleksi.

Dari hasil siklus I diperoleh data Hasil belajar matematika siswa kelas XI MIPA 3 diukur dengan bentuk soal uraian sebanyak delapan butir yang diikuti oleh 36 orang siswa (data terlampir). Pada hasil belajar matematika siswa (Siklus I), jumlah siswa tuntas adalah 21 orang $(58,33 \%)$, dan jumlah siswa yang belum tuntas adalah 15 orang $(41,67 \%)$. Dari data tersebut dapat diketahui bahwa hasil belajar matematika siswa mengalami peningkatan jika dibandingkan dengan hasil belajar matematika siswa sebelum dilakukan penelitian tindakan (Pra siklus). Presentase peningkatan ketuntasannya adalah sebesar $41,66 \%$, yakni meningkat dari $16,67 \%$ menjadi $58,33 \%$. Presentase peningkatan yang sebesar $41,66 \%$ menurut peneliti adalah menakjubkan, karena pada hasil-hasil belajar sebelumnya, yaitu sebelum dilakukan penelitian tindakan adalah sangat rendah, hanya belasan persen saja setiap dilakukan kegiatan evaluasi pembelajaran. Akan tetapi, walaupun terjadi peningkatan ketuntasan hasil belajar yang signifikan, penelitian ini belum bisa dikatakan berhasil karena kriteria keberhasilan penelitian tindakan kelas ini adalah ketika jumlah siswa tuntas minimal mencapai 29 orang atau dengan kata lain presentasenya mencapai $80 \%$.

Selanjutnya pada siklus ke II diperoleh data Hasil belajar matematika siswa kelas XI MIPA 3 diukur dengan bentuk soal uraian sebanyak delapan butir yang diikuti oleh 36 orang siswa (data terlampir). Pada hasil belajar matematika siswa (Siklus II), jumlah siswa tuntas adalah 24 orang $(66,67 \%)$, dan jumlah siswa yang belum tuntas adalah 12 orang $(33,33 \%)$. Dari data tersebut dapat diketahui bahwa hasil belajar matematika siswa mengalami peningkatan jika dibandingkan dengan hasil belajar matematika siswa pada siklus I. Presentase peningkatan ketuntasannya adalah sebesar $8,34 \%$, yakni meningkat dari $58,33 \%$ menjadi $66,67 \%$. Adanya peningkatan presentase ketuntasan dari siklus I ke siklus II bagi peneliti adalah suatu kabar gembira, karena hal itu berarti peneliti dalam melakukan refleksi dan tindak lanjut dari siklus I membuahkan hasil berupa peningkatan presentase ketuntasan pada siklus II. Akan tetapi, walaupun terjadi peningkatan presentase ketuntasan hasil belajar yang signifikan, penelitian ini belum bisa dikatakan berhasil karena kriteria keberhasilan penelitian tindakan kelas ini adalah ketika jumlah siswa tuntas minimal mencapai 29 orang atau dengan kata lain presentasenya mencapai $80 \%$.
Dan pada siklus terakhir yaitu siklus ke III diperoleh data Hasil belajar matematika siswa kelas XI MIPA 3 diukur dengan bentuk soal uraian sebanyak delapan butir yang diikuti oleh 36 orang siswa (data terlampir). Pada hasil belajar matematika siswa (Siklus III), jumlah siswa tuntas adalah 29 orang $(80,56 \%)$, dan jumlah siswa yang belum tuntas adalah 7 orang $(19,44 \%)$. Dari data tersebut dapat diketahui bahwa hasil belajar matematika siswa mengalami peningkatan jika dibandingkan dengan hasil belajar matematika siswa pada siklus II. Presentase peningkatan ketuntasannya adalah sebesar $13,89 \%$, yakni meningkat dari $66,67 \%$ menjadi $80,56 \%$.

Hasil Penelitian Tindakan Kelas (PTK) yang dilaksanakan di kelas XI MIPA 3 SMAN 1 Leuwiliang semester genap tahun pelajaran 2017/2018 dalam upaya meningkatkan hasil belajar matematika siswa pada materi turunan fungsi aljabar melalui model pembelajaran kooperatif tipe team games tournament (TGT) yang dilaksanakan dalam tiga siklus menunjukkan adanya peningkatan hasil belajar matematika siswa. Untuk lebih jelasnya dapat disajikan dalam tabel hasil belajar matematika siswa pada siklus I, II, dan III berikut:

Berdasarkan hasil tes individu terhadap keberhasilan pembelajaran pada siklus I, II, dan III, dapat dibuatkan rekapitulasi sebagai berikut:

Tabel 1. Rekapitulasi Hasil Belajar Matematika Siswa Pada Siklus I, II, dan III.

\begin{tabular}{|c|c|c|c|c|c|}
\hline & & & & & \\
\hline \multirow{2}{*}{ No. } & \multirow{2}{*}{$\begin{array}{c}\text { Interval } \\
\text { Nilai }\end{array}$} & \multicolumn{4}{|c|}{ Frekuensi } \\
\hline & & $\begin{array}{l}\text { Pra } \\
\text { Siklus }\end{array}$ & $\begin{array}{c}\text { Siklus } \\
\text { I }\end{array}$ & $\begin{array}{l}\text { Siklus } \\
\text { II }\end{array}$ & $\begin{array}{l}\text { Siklus } \\
\text { III }\end{array}$ \\
\hline 1 & $10-22$ & 4 & 0 & 3 & 0 \\
\hline 2 & $23-35$ & 10 & 4 & 1 & 4 \\
\hline 3 & $36-48$ & 9 & 3 & 2 & 1 \\
\hline 4 & $49-61$ & 0 & 3 & 3 & 2 \\
\hline 5 & $62-74$ & 7 & 5 & 3 & 0 \\
\hline 6 & $75-87$ & 2 & 11 & 9 & 12 \\
\hline 7 & $88-100$ & 4 & 10 & 15 & 17 \\
\hline \multicolumn{2}{|c|}{ Nilai Rata-rata } & 47,39 & 72,39 & 75,03 & 79,28 \\
\hline \multicolumn{2}{|c|}{$\begin{array}{c}\text { Jumlah Siswa } \\
\text { Tuntas }\end{array}$} & $\begin{array}{c}6 \\
\text { orang }\end{array}$ & $\begin{array}{c}21 \\
\text { orang }\end{array}$ & $\begin{array}{c}24 \\
\text { orang }\end{array}$ & $\begin{array}{c}29 \\
\text { orang }\end{array}$ \\
\hline
\end{tabular}

Dari tabel di atas dapat digambarkan dalam bentuk grafik sebagai berikut:

\section{Hasil Belajar Matematika Siklus I,} II, dan III

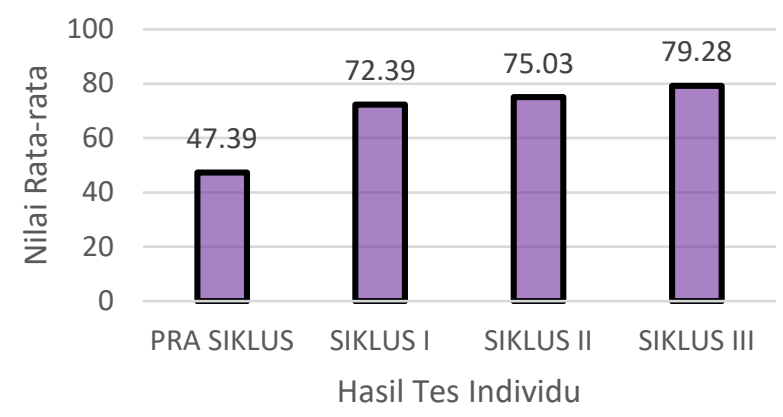


Yeni Yulianti ${ }^{1}$, Mohamad Syafi' ${ }^{2}{ }^{2}$, Abdul Hakim Ma'ruf ${ }^{3}$ : Upaya Meningkatkan Hasil Belajar Matematika melalui Model Pembelajaran TGT pada Materi Turunan Fungsi Aljabar

Gambar 1. Rekapitulasi Hasil Belajar Matematika Siswa Pada Siklus I, II, dan III

Sedangkan tingkat ketuntasan hasil belajar siswa pada siklus I, II, dan III dapat dilihat pada tabel dan grafik berikut:

Tabel 2. Rekapitulasi Tingkat Ketuntasan Hasil Belajar Matematika Siswa Pada Siklus I, II, dan III

\begin{tabular}{|c|c|c|c|}
\hline \multicolumn{4}{|c|}{ Ketuntasan Hasil Belajar Matematika Siswa } \\
\hline Pra Siklus & Siklus I & Siklus II & Siklus III \\
\hline $16,67 \%$ & $58,33 \%$ & $66,67 \%$ & $80,56 \%$ \\
\hline
\end{tabular}

Dari tabel di atas dapat digambarkan dalam bentuk grafik sebagai berikut:

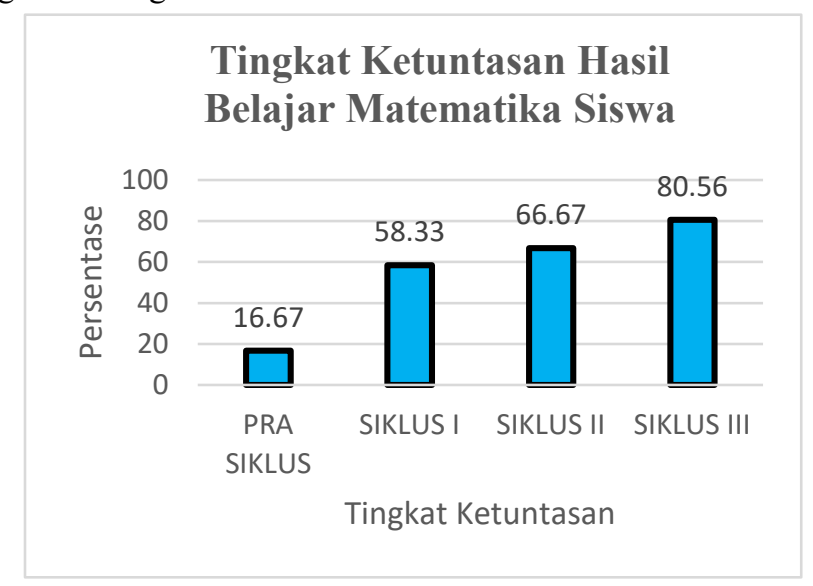

Gambar 2. Rekapitulasi Tingkat Ketuntasan Hasil Belajar Matematika Siswa Pada Pra Siklus, SiklusI, Siklus

$$
\text { II, dan Siklus III }
$$

Berdasarkan tabel dan grafik di atas dapat diketahui bahwa hasil belajar matematika siswa mengalami peningkatan, yaitu pada pra siklus (kemampuan awal siswa sebelum dilakukan penelitian tindakan)nilai rata-rata hasil tes individu hanya mencapai angka 47,39 dengan tingkat ketuntasan hanya $16,67 \%$, sedangkan setelah dilakukan penelitian tindakan pada siklus I nilai rata-rata hasil tes individu meningkat menjadi 72,39 dengan tingkat ketuntasan sebesar 58,33\%, kemudian pada siklus II nilai rata-rata hasil tes individu juga meningkat menjadi 75,03 dengan tingkat ketuntasan sebesar $66,67 \%$ dan pada siklus III nilai rata-rata hasil tes individu mencapai angka 79,28 dengan tingkat ketuntasan sebesar 80,56\%.

Berdasarkan pada peningkatan-peningkatan tingkat ketuntasan tiap siklus, terutama pada siklus III yang tingkat ketuntasannya mencapai angka 80,56\%, maka hal ini menunjukkan bahwa pada siklus III ini penelitian sudah mencapai kriteria keberhasilan penelitian yang tetapkan. Hal ini juga berarti bahwa upaya meningkatkan hasil belajar matematika siswa melalui model pembelajaran kooperatif tipe team games tournament (TGT) di kelas XI MIPA 3 SMAN 1 Leuwiliang semester genap tahun pelajaran 2017/2018 pada materi turunan fungsi aljabar telah berhasil.

Dari hasil wawancara kepada siswa diperoleh. 1) Siswa menyukai model pembelajaran kooperatif tipe team games tournament (TGT) yang diterapkan pada materi turunan fungsi aljabar karena seru. Menurut mereka lebih seru belajar menggunakan metode TGT dari pada menggunakan metode yang biasa digunakan, lebih seru main game turnamen TGT, membuat tidak cepat mengantuk saat belajar karena pada saat pembelajaran kadang banyak bercanda dan tertawa, membuat siswa bisa berbagi pengetahuan dengan yang lainnya, membuat suasana dalam kelompok menjadi lebih akrab, dan membuat siswalebih termotivasi dalam belajar karena ada rasa bersaing antar kelompok. 2) Kesulitan yang dialami siswa selama kegiatan belajar menggunakan model pembelajaran kooperatif tipe team games tournament (TGT) adalah disebabkan beberapa hal, diantaranya adalah siswa tidak mengikuti secara lengkap tahapan kegiatan pembelajaran. Contohnya pada kegiatan pembelajaran tim siklus I, salah satu siswa pernah tidak masuk 1 kali karena sakit dan 6 orang siswa berprestasi tinggi tidak mengikuti satu tahap dalam metode TGT karena mereka dispensasi mengikuti lomba di luar sekolah, padahal mereka sebelumnya mengikuti kegiatan presentasi kelas, hal itu membuat hasil belajar mereka kurang maksimal, mereka sangat kebingungan mengikuti metode TGT karena ada tahapan yang mereka tidak ikuti, begitu pula yang dirasakan oleh siswa-siswa yang lainnya yang melewatkan satu tahap dalam pembelajaran metode TGT karena tidak hadir. Selain itu, pada siklus I dan II ternyata pengelompokkan siswa ternyata masih belum proporsional, masih belum benar-benar heterogen/homogen, sehingga beberapa siswa berprestasi tinggi mengeluh karena mereka kesulitan melakukan tutor sebaya disebabkan komposisi siswa berprestasi rendah lebih banyak ada dalam kelompok siswa tersebut. Jadi, pengelompokkan siswa dalam TGT harus benar-benar proporsional, heterogentetapi homogen. 3) Siswa merasa senang belajar menggunakan model pembelajaran kooperatif tipe team games torunament (TGT). Ada siswa yang sangat senang karena selama belajar menggunakan model pembelajaran kooperatif tipe team games tournament (TGT) selama tiga siklus nilai tes individunya semuanya bagus dan mencapai KKM, padahal sebelumnya nilai tes matematikanya sering belum mencapai KKM.

\section{PENUTUP}




\section{Simpulan}

Berdasarkan dari hasil penelitian dan pembahasan dapat disimpulkan bahwa 1). Hasil belajar matematika siswa mengalami peningkatan. Hal ini dapat dilihat dari hasil tes individu yaitu pada pra siklus (kemampuan awal siswa sebelum dilakukan penelitian tindakan) nilai rata-rata hasil tes individu hanya mencapai angka 47,39 dengan tingkat ketuntasan hanya $16,67 \%$, sedangkan setelah dilakukan penelitian tindakan pada siklus I nilai rata-rata hasil tes individu meningkat menjadi 72,39 dengan tingkat ketuntasan sebesar $58,33 \%$, kemudian pada siklus II nilai rata-rata hasil tes individu juga meningkat menjadi 75,03 dengan tingkat ketuntasan sebesar $66,67 \%$ dan pada siklus III nilai rata-rata hasil tes individu mencapai angka 79,28 dengan tingkat ketuntasan sebesar $80,56 \%$. 2). Pelaksanaan pengajaran dengan menggunakan model pembelajaran kooperatif tipe team games tournament (TGT) cocok diterapkan pada materi turunan fungsi aljabar. 3). Penerapan model pembelajaran kooperatif tipe team games tounament (TGT) sangat menarik untuk siswa, menumbuhkan kepercayaan diri siswa, menumbuhkan persaingan yang sehat, dan keberanian pada setiap individu siswa. 4). Siswa menyukai model pembelajaran kooperatif tipe team games tournament (TGT) yang diterapkan pada materi turunan fungsi aljabar dan siswa merasa senang belajar menggunakan model pembelajaran kooperatif tipe team games tournament (TGT).

\section{Saran}

Berdasarkan kesimpulan penelitian ini, yaitu penggunaan model pembelajaran kooperatif tipe team games torunament (TGT) dapat meningkatkan hasil belajar matematika siswa, maka tim kolaborator atau peneliti memberikan saran sebagai berikut:

1. Bagi Sekolah

a. Kepala Sekolah diharapkan memotivasi dan memfasilitasi dengan positif bagi guru yang ingin melakukan Penelitian Tindakan Kelas (PTK) guna meningkatkan hasil belajar siswa.

b. Kepala Sekolah diharapkan memberikan penghargaan (reward) terhadap guru yang berdedikasi tinggi dan berprestasi agar selalu berkomitmen untuk memajukan sekolah melalui Penelitian Tindakan Kelas (PTK).

2. Bagi Guru

a. Dalam kegiatan belajar mengajar guru diharapkan menjadikan model pembelajaran kooperatif tipe team games tournament (TGT) sebagai suatu alternatif dalam pemilihan model maupun metode pembelajaran untuk meningkatkan keaktifan siswa dan hasil belajar siswa. b. Guru diharapkan agar membiasakan diri mencari inovasi baru dalam mengajar sehingga pembelajaran tidak monoton, menerapkan metode pembelajaran yang menyenangkan.

c. Guru diharapkan untuk selalu berusaha memberikan motivasi kepada siswa di setiap proses kegiatan belajar mengajar.

d. Karena kegiatan ini sangat bermanfaat khususnya bagi guru dan siswa, maka diharapkan kegiatan ini dapat dilakukan secara berkesinambungan dalam pembelajaran mata pelajaran matematika maupun pada mata pelajaran lainnya.

\section{DAFTAR PUSTAKA}

Iktikaviana, N. L. (2012). Penggunaan Model Pembelajaran Team Game Tournament (Tgt) Untuk Meningkatkan Hasil Belajar Siswa Materi Operasi Hitung Bilangan Bulat Positif Dan Negatif Siswa Kelas Iv Sdn Bandung 02 Gedeg Mojokerto (Doctoral dissertation, University of Muhammadiyah Malang).

Kusumah, Wijaya dan Dedi Dwitagama. (2012) Mengenal Penelitian Tindakan Kelas. Jakarta: PT. Indeks.

Kusuma, A. P., \& Khoirunnisa, A. (2018). Penerapan Model Pembelajaran Kooperatif Tipe Make a Match dan Team Games Tournament terhadap Hasil Belajar. NUMERICAL: Jurnal Matematika dan Pendidikan Matematika, 1-14.

Mangentang, D. F., Kusuma, A. P., Arihati, D. B., \& Rahmawati, N. K. (2018, September). Penerapan Model Pembelajaran Brain Based Learning Dan Model Pembelajaran Accelerated Learning Cycle Terhadap Hasil Belajar Matematika Pada Materi Logaritma. In Seminar Nasional dan Diskusi Panel Multidisiplin Hasil Penelitian dan Pengabdian Kepada Masyarakat 2018 (Vol. 1, No. 1).

Purnamasari, Y. (2013). Pengaruh Model Pembelajaran Kooperatif Tipe Teams Games-Tournament (TGT) Terhadap Kemandirian Belajar Dan Peningkatan Kemampuan Penalaran Dan Koneksi Matematik Peserta Didik SMPN 1 Kota Tasikmalaya (Doctoral dissertation, Universitas Terbuka).

Rahmawati, N. K., \& Setiani, S. (2018). Eksperimentasi Model Pembelajaran Snowball Throwing dan NHT Ditinjau dari Gaya Belajar Siswa pada Materi Himpunan Kelas VII SMP Avicenna Cileungsi.. Jurnal Pendidikan Matematika dan IPA, 10(1), 41-51.

Rusman. (2016) Model-model Pembelajaran. Jakarta: Rajagrafindo Persada.

Solihah, A. (2016). Pengaruh Model Pembelajaran Teams Games Tournament (TGT) terhadap Hasil Belajar Matematika. SAP (Susunan Artikel Pendidikan), 1(1).

Susyanto, A. D. (2015). Upaya Meningkatkan Hasil Belajar Matematika Melalui Pembelajaran Kooperatif Tipe Team Games Tournamen Pada Siswa Kelas V Sd N 1 Jembangan Poncowarno Kebumen. Universitas PGRI Yogyakarta. 
Yeni Yulianti ${ }^{1}$, Mohamad Syafi' ${ }^{2}{ }^{2}$, Abdul Hakim Ma'ruf ${ }^{3}$ : Upaya Meningkatkan Hasil Belajar Matematika melalui Model Pembelajaran TGT pada Materi Turunan Fungsi Aljabar

Triyani, A. N. (2009). Model Pembelajaran Kooperatif Tipe Teams-Games-Tournament (TGT) Sebagai Upaya Meningkatkan Keaktifan Belajar Matematika Siswa Pada Pokok Bahasan Peluang Dan Statistika Di SMP Negeri 4 Depok Yogyakarta Kelas IX C. Universitas Negeri Yogyakarta, Yogyakarta.

Yamin,Moh.(2015) Teori Dan Metode Pembelajaran. Malang: Madani. 